\title{
PENGARUH LATIHAN LARI ZIG-ZAG, LARI BOLAK-BALIK, PUSH-UP DENGAN POLA CIRCUIT TRAINING TERHADAP KESEGARAN JASMANI SISWA EKSTRAKURIKULER SEPAK BOLA SMAN I SOA TAHUN AJARAN 2015/2016
}

\author{
Wiljiwianus Primus Wio Bei \\ Pendidikan Jasmani Kesehatan dan Rekreasi \\ STKIP Citra Bakti \\ E-mail: primuscitrabakti@gmail.com
}

Diterima: 11 Oktober 2017; Lolos: 16 November 2017; Dipublikasikan: 16 November 2017

\begin{abstract}
Abstrak
Tujuan penelitian ini adalah untuk mengetahui pengaruh latihan lari zig-zag, lari bolak-balik, push-up dengan pola circuit training studi pada siswa ekstrakurikuler sepak bola SMAN 1 Soa. Penelitian ini adalah penelitian eksperimen dengan desain the static -group pretest - posttest design. Sampel penelitian ini sebanyak 40 orang terdiri atas 20 orang adalah kelompok eksperimen dan 20 orang kelompok kontrol yang diambil secara random. Untuk mengumpulkan data peningkatan Kesegaran Jasmani digunakan TKJI, kemudian data dianalisis dengan $t$-test. Hasil analisis menunjukan bahwa nilai $t_{\text {hitung }}$ sebesar 3,5 lebih besar dari nilai $t_{\text {tabel }} 2,042$ pada taraf signifikasi $5 \%(\alpha=0,05)$. Ini berarti ada perbedaan yang signifikan Kesegaran Jasmani antara kelompok eksperimen dan kelompok kontrol. Dengan demikian dapat disimpulkan bahwa latihan lari zig-zag, lari bolak-balik, push up dengan pola circuit training berpengaruh terhadap kesegaran jasmani pada siswa peserta ektrakurikuler sepak bola SMAN 1 Soa.
\end{abstract}

Kata kunci: Lari zig-zag, lari bolak-balik, push-up, circuit training, kesegaran jasmani.

\section{EFFECT OF EXERCISE ZIG-ZAG RUN, BACK AND FORTH RUN, PUSH UP WITH CIRCUIT TRAINING SYSTEM TO PHYSICAL FITNESS ON FOOTBALL EXTRACURRICULAR STUDENTS OF SENIOR HIGH SCHOOL SOA I YEAR LEARNING 2015/2016}

\begin{abstract}
This research aimed at finding out the effect of zig-zag run training, back and forth run, push up with circuit training toward physical health (study on football extracurricular students of Senior High School Soa). This research was experiment research with the static-group prestest-posttest design. The sample of this research as much as 40 students consisted of 20 students for experiment group and 20 students for control group which taken randomly. In order to collect the physical health upgrading data used TKJI, then data analyzed by T-test. The result of the analysis showed that score $t_{\text {count }}$ in amount of 3,5 bigger than score $t_{\text {table }} 2.042$ on significance level $5 \%(\alpha 0.05)$. This means there is significance effect of physical health between experiment group and control group. Thus, it can be concluded that zig-zag run training, back and forth run,
\end{abstract}

Email : primuscitrabakti@gmail.com

No Handphone : 081337889429
(C)2017 UN PGRI Kediri

p-ISSN: $2548-7833$

e-ISSN: $2477-3379$ 
Wiljiwianus Primus Wio Bei

Pengaruh Latihan Lari Zig-Zag, Lari Bolak-Balik, Push Up dengan Pola Circuit Training Terhadap Kesegaran Jasmani Siswa Ekstrakurikuler Sepak Bola SMAN I Soa Tahun Ajaran 2015/2016

push up with circuit training influenced toward physical health on football extracurricular students of Soa Senior High School.

Keywords: Zig-zag run, back and forth run, push-up, circuit training, physical fitness.

\section{PENDAHULUAN}

Pendidikan pada umumnya sangat erat dengan pendidikan jasmani. Pendidikan jasmani adalah proses pendidikan yang diarahkan untuk mendorong, membimbing, mengembangkan dan membina kemampuan jasmani dan rohani serta kesehatan siswa dan lingkungan hidupnya agar tumbuh dan berkembang secara harmonis dan optimal sehingga mampu melaksanakan tugas bagi dirinya dan untuk membangun bangsa melalui aktifitas jasmani yang dilakukan secara teratur. Kegiatan olahraga yang dilakukan secara baik dan benar memiliki dampak positif dalam perkembangan siswa baik di sekolah maupun di lingkungan masyarakat. Olahraga mempunyai peran penting dalam kehidupan manusia, dalam kehidupan modern manusia tidak bisa dipisahkan dari kegiatan olahraga baik meningkatkan prestasi maupun kesehatan tubuh.

Berolahraga dapat membentuk manusia sehat jasmani dan rohani serta mempunyai watak disiplin dan pada akhirnya memembentuk perkembangan manusia yang berkualitas. Perkembangan dan pertumbuhan anak sangat penting untuk diperhatikan sebab mereka adalah aset yang sangat berharga dalam perkembangan jaman nantinya. Anak merupakan tunas bangsa yang sedang tumbuh dan berkembang sehingga menjadi harapan sebagai generasi penerus di masa akan datang. Salah satu bentuk kegiatan untuk mendukung mereka aktif bergerak adalah kegiatan ekstrakurikuler.

Ekstrakurikuler adalah kegiatan diluar kurikulum yang dapat menambah pengetahuan keterampilan siswa. Oleh karena itu, ekstrakurikuler pada dasarnya adalah aktifitas penunjang dan sarana untuk mengembangkan minat dan bakat siswa. Salah satu contoh kegiatan ekstrakurikuler adalah permainan sepak bola.

Permainan sepak bola adalah permainan yang sederhana, dan rahasia permainan sepak bola yang baik ialah melakukan hal-hal SPORTIF, 3 (2) 2017 | 203-215 
Wiljiwianus Primus Wio Bei

Pengaruh Latihan Lari Zig-Zag, Lari Bolak-Balik, Push Up dengan Pola Circuit Training Terhadap Kesegaran Jasmani Siswa Ekstrakurikuler Sepak Bola SMAN I Soa Tahun Ajaran 2015/2016

sederhana dengan sebaik-baiknya, Batty (2003). Menurut Muhajir (2007:22)," sepak bola adalah suatu permainan yang dilakukan dengan jalan menyepak, yang mempunyai tujuan untuk memasukan bola ke gawang lawan dengan mempertahankan gawang tersebut agar tidak kemasukan bola". Menurut Luxbacher (2008: 2) pertandingan sepak bola dimainkan dua tim yang masisng-masing beranggotakan sebelas orang. Masing-masing mempertahankan gawang sendiri dan berusaha menjebol gawang lawan.Nilai positif dari pada sepak bola sendiri adalah meningkatkan kebugaran jasmani.

Kebugaran jasmani yang terkait dengan kesehatan adalah kemampuan seseorang melakukan tugas fisik yang memerlukan kekuatan, daya tahan, dan fleksibilitas, kebugaran itu dicapai melalui sebuah kombinasi dari latihan teratur dan kemampuan yang melekat pada seseorang (Lutan, 2002:7-8).

Metode circuit training adalah suatu cara latihan bertujuan untuk meningkatkan kebugaran jasmani, meningkatkan perkembangan kekuatan dan daya tahan otot, serta daya tahan sistem peredaran darah dan pernapasan (circolorespiratory endurance). Pada saat melakuakn suatu circuit traning ditentukan oleh beberapa pos dan pada setiap pos harus melakukan suatu bentuk latihan tertentu baik dengan beban atau tanpa beban. Bentuk- bentuk latihan harus disesuaikan dengan tujuan latihan.

Penelitian dilakukan di SMAN 1 Soa karena selama ini metode latihan lari zig-zag, lari bolak balik, push-up dengan pola circuit training belum pernah diterapkan dalam latihan pada sekolah tersebut dan belum diketahui pengaruhnya terhadap physical fitness. Selanjutnya peneliti menawarkan salah satu bentuk latihan yang dapat dilakukan untuk meningkatkan kondisi fisik dan tingkat kesegaran jasmani siswa ekstrakurikuler sepak bola di SMAN 1 Soa Kabupaten Ngada adalah circuit training.

Menurut Wayne (2003: 3) circuit training merupakan model latihan yang melibatkan serangkaian latihan yang berbeda yang dilakukan secara berurutan dan terus-menerus selama satu putaran/sirkuit. Model circuit 
Wiljiwianus Primus Wio Bei

Pengaruh Latihan Lari Zig-Zag, Lari Bolak-Balik, Push Up dengan Pola Circuit Training Terhadap Kesegaran Jasmani Siswa Ekstrakurikuler Sepak Bola SMAN I Soa Tahun Ajaran 2015/2016

training harus disesuaikan dengan karakter cabang olahraga yang ditekuni atlet. Oleh karena itu penyusunan dan merencanakan proses latihan harus memperhatiakn komponen-komponen latihan.

Kesegaran jasmani yaitu kemampuan seseorang untuk melaksanakan tugas sehari-hari tanpa menimbulkan kelelahan yang berarti (Suharto, 2001: 1). Senada dengan pendapat tersebut, Suroto (2004:2) kebugaran jasmani adalah kemampuan atau kesanggupan seseorang untuk melakukan aktivitas atau kegiatan dengan daya kerja tinggi tanpa mengalami kelelahan yang berarti atau berlebihan.

Menurut Sajoto (1995: 8), bahwa komponen kesegaran jasmani meliputi 10 komponen. Adapun 10 komponen kesegaran jasmani adalah sebagai berikut: 1)kekuatan (strength), 2) daya tahan (endurance), 3) daya otot (muscular power), 4)kecepatan (speed), 5) daya lentur (flexibility), 6) kelincahan (agility), 7)koordinasi (coordination), 8) keseimbangan (balance), 9) ketepatan (accuracy), 10) reaksi (reaction).

\section{METODE PENELITIAN}

Sesuai dengan tujuan penelitian yaitu untuk mengetahui apakah ada pengaruh latihan lari zig-zag, lari bolak-balik, push up, terhadap kesegaran jasmani siwa ektrakurikuler sepak bola SMAN 1 Soa maka metode dalam penelitian ini menggunakan metode atau pendekatan eksperimental dengan rancangannya (desain) The Static-Group PretestPostest Design.

\begin{tabular}{ccc}
$\mathrm{O} 1$ & $\mathrm{x}_{1}$ & $\mathrm{O}_{2}$ \\
\hdashline $\mathrm{O}_{3}$ & $\mathrm{x}_{2}$ & $\mathrm{O}_{4}$
\end{tabular}

Keterangan :

O1: Pre test kelompok ekperimen

O2 : Post test kelompok eksperimen

O3 : Pre test kelompok kontrol

O4 : Post test kelompok kontrol

$\mathrm{X} 1$ : Treatment kelompok eksperimen

X2 : Latihan konvesional (latihan yang sesuai dengan kebiasaan sampel) 
Wiljiwianus Primus Wio Bei

Pengaruh Latihan Lari Zig-Zag, Lari Bolak-Balik, Push Up dengan Pola Circuit Training Terhadap Kesegaran Jasmani Siswa Ekstrakurikuler Sepak Bola SMAN I Soa Tahun Ajaran 2015/2016

Dianalisis dengan "gain score " or "change", yaitu skor post-test dikurangi skor pre-test. Kalau ada peningkatan skor, Artinya treatment tersebut berpengaruh terhadap peningkatan skor variable terikat.

Populasi dalam penelitian ini adalah keseluruhan obyek yang digunakan sebagai penelitian yang mempunyai satu atau beberapa ciri yang sama. Sedangkan populasi dalam penelitian ini adalah siswa peserta ektrakurikuler sepak bola SMAN 1 Soa yang berjumlah 60 orang. Selanjutnya sampel yang digunakan adalah 40 orang. teknik sampling yang digunakan dalam penelitian ini menggunakan metode simple random sampling untuk menentukan kelompok eksperimen dan kelompok kontrol. Penelitian eksperimen ini menggunakan dua variabel, yaitu variabel bebas dan variabel terikat. Variabel bebas dalam penelitian ini adalah lari zigzag, lari bolak-balik dan push up yaitu variabel perlakuan yang mempengaruhi kemampuan kebugaran jasmani. Sedangkan variabel terikat dalam penelitian ini adalah tingkat kebugaran jasmani yang merupakan akibat dari adanya lari zig-zag, lari bolak-balik, push up dengan pola circuit training.

Untuk mengumpulkan data pengaruh latihan lari zig-zag, lari bolakbalik dan push up terhadap physical fitness dengan menggunakan Test Kesegran Jasmani Indoneia (TKJI) dengan kriteria umur 16-19 tahun (Mahardika, 2014:139)

Sebelum dilakukan analisis pengujian hipotesis, terlebih dahulu melakukan pengujian persyaratan hipotesis yaitu uji normalitas dan uji homogenitas dengan menggunakan SSPS 16.0 for window. Uji normalitas tidak lain sebenarnya adalah mengadakan pengujian terhadap normal tidaknya sebaran data yang akan dianalisis. Pengujian dilakukan tergantung variabel yang akan diolah. Pengujian normalitas sebaran data menggunakan Kolmogorov Smirnov Test dengan bantuan SPSS 16.0 Menurut metode Kolmogorov Smirnov, kriteria pengujian adalah sebagai berikut: 
Wiljiwianus Primus Wio Bei

Pengaruh Latihan Lari Zig-Zag, Lari Bolak-Balik, Push Up dengan Pola Circuit Training Terhadap Kesegaran Jasmani Siswa Ekstrakurikuler Sepak Bola SMAN I Soa Tahun Ajaran 2015/2016

1. Jika signifikansi di bawah 0,05 (5\%) berarti data yang akan diuji mempunyai perbedaan yang signifikan dengan data normal baku, berarti data tersebut tidak normal.

2. Jika signifikansi di atas 0,05 (5\%) maka berarti tidak terdapat perbedaan yang signifikan antara data yang akan diuji dengan data normal baku, berarti data tersebut normal.

Uji homogenitas varians dilakukan untuk mengetahui kesamaan sampel yaitu kelompok eksperimen dan kelompok kontrol harus mempunyai kemampuan awal yang sama sehingga dapat diketahui pengaruh setelah diberi perlakuan yang berbeda pada kedua kelompok tersebut. Kriteria pengujian yang diajukan Ho di terima $p$-value $>0,05$ maka tes dinyatakan homogen.

Untuk menguji hipotesis penelitian digunakan uji t dengan rumus sebagai berikut.

Rumus :

$$
t=\frac{\bar{X}_{1}-\bar{X}_{2}}{\sqrt{\frac{s_{1}{ }^{2}}{n_{1}}+\frac{s_{2}{ }^{2}}{n_{2}}}}
$$

1. Jika $t_{\text {hitung }}$ sama atau lebih besar dari $t_{\text {tabel }}$ pada taraf $5 \%$ maka Ho ditolak dan $\mathrm{H} 1$ diterima. Ini berarti ada perbedaan yang signifikan latihan lari zig, lari bolak-balik, push up dengan pola circuit training antara kelompok eksperimen dan kelompok kontrol. Jika rata - rata hitung kelompok eksperimen lebih besar dari rata - rata hitung kelompok kontrol, maka ada pengaruh yang signifikan latihan lari zigzag, lari bolak-balik, push up dengan pola circuit training terhadap kesegaran jasmani studi pada siswa ektrakurikuler sepak bola SMAN 1 Soa.

2. Jika $t_{\text {hitung }}$ lebih kecil dari $t_{\text {tabel }}$ maka Ho diterima dan $\mathrm{H} 1$ ditolak, ini berarti tidak ada perbedaan yang signifikan latihan lari zig, lari bolakbalik, push-up dengan pola circuit trainingantara kelompok eksperimen dan kelompok kontrol. Jika rata - rata hitung kelompok eksperimen lebih besar dari rata - rata hitung kelompok kontrol, maka ada 
Wiljiwianus Primus Wio Bei

Pengaruh Latihan Lari Zig-Zag, Lari Bolak-Balik, Push Up dengan Pola Circuit Training Terhadap Kesegaran Jasmani Siswa Ekstrakurikuler Sepak Bola SMAN I Soa Tahun Ajaran 2015/2016

pengaruh yang signifikan latihan lari zig-zag, lari bolak-balik, push-up dengan pola circuit training terhadap kesegaran jasmani studi pada siswea ektrakurikuler sepak bola SMAN 1 Soa

\section{HASIL PENELITIAN}

Penelitian ini dilaksanakan di SMAN 1 Soa dengan mengambil populasi siswa putra peserta ektrakurikuler sepak bola dan keseluruhan populasi tersebut akan dibagi menjadi dua kelompok, dimana kelompok pertama untuk kelompok eksperimen dan kelompok kedua untuk kelas kontrol. Melalui random sampling dengan cara di undi pada siswa yang sudah di bagi dalam dua kelompok yaitu kelompok eksperimen dan kelompok kontrol dengan total responden sebanyak 40 orang. Sebelum di berikan perlakuan latihan lari zig zag, lari bolak-balik, dan push up terlebih dahulu siswa yang sudah terbagi dalam kedua kelompok diberikan 5 item tes TKJI guna pengambilan data awal (pre-test), yang bertujuan untuk mengetahui kemampuan awal dari kedua kelompok siswa baik pada kelompok eksperimen maupun kelompok kontrol sebelum diberi perlakuan. Data pre-test akan digunakan untuk membandingkan dengan hasil post-test (tes akhir). Tes akhir (post-test) dilakukan setelah siswa diberikan latihan lari zig-zag, lari bolak-balik, dan push up untuk kelompok eksperimen.

Berdasarkan beberapa test yang dilakukan maka diperoleh data hasil tes latihan lari zig-zag, lari bolak balik, dan push up dengan pola circuit training terhadap kesegaran jasmani sebagai berikut:

Tabel 1 Gain Score Normal, Gain Score normal dikuadratkan Kelompok Kontrol dan Kelompok Eksperimen.

\begin{tabular}{lllllllll}
\hline $\begin{array}{c}\text { No. } \\
\text { Resp }\end{array}$ & \multicolumn{4}{c}{ EKSPERIMEN } & \multicolumn{5}{c}{ KONTROL } \\
\cline { 2 - 9 } & $\begin{array}{c}\text { Pre- } \\
\text { Test }\end{array}$ & $\begin{array}{c}\text { Post- } \\
\text { Test }\end{array}$ & $\begin{array}{l}\text { Gain } \\
\text { Score }\end{array}$ & GSn & $\begin{array}{c}\text { Pre- } \\
\text { Test }\end{array}$ & $\begin{array}{c}\text { Post- } \\
\text { Test }\end{array}$ & $\begin{array}{c}\text { Gain } \\
\text { Score }\end{array}$ & GSn \\
\hline 1 & 15 & 21 & 6 & 0,071 & 14 & 17 & 3 & 0,035 \\
\hline 2 & 16 & 25 & 9 & 0,107 & 14 & 18 & 4 & 0,047 \\
\hline 3 & 11 & 24 & 13 & 0,146 & 17 & 19 & 2 & 0,024 \\
\hline 4 & 10 & 18 & 8 & 0,089 & 14 & 21 & 7 & 0,081 \\
\hline 5 & 10 & 20 & 10 & 0,111 & 16 & 19 & 3 & 0,036 \\
\hline 6 & 12 & 18 & 6 & 0,069 & 10 & 18 & 8 & 0,089 \\
\hline 7 & 14 & 25 & 11 & 0.128 & 14 & 24 & 10 & 0,116 \\
\hline
\end{tabular}


Wiljiwianus Primus Wio Bei

Pengaruh Latihan Lari Zig-Zag, Lari Bolak-Balik, Push Up dengan Pola Circuit Training Terhadap Kesegaran Jasmani Siswa Ekstrakurikuler Sepak Bola SMAN I Soa Tahun Ajaran 2015/2016

\begin{tabular}{lllllllll}
\hline 8 & 12 & 23 & 11 & 0,125 & 17 & 20 & 3 & 0,037 \\
\hline 9 & 15 & 23 & 8 & 0,094 & 14 & 21 & 7 & 0,081 \\
\hline 10 & 13 & 19 & 6 & 0,069 & 10 & 18 & 8 & 0,089 \\
\hline 11 & 13 & 20 & 7 & 0,080 & 18 & 22 & 4 & 0,049 \\
\hline 12 & 12 & 25 & 13 & 0,148 & 15 & 20 & 5 & 0,059 \\
\hline 13 & 14 & 21 & 7 & 0,081 & 19 & 23 & 4 & 0,049 \\
\hline 14 & 14 & 23 & 9 & 0,105 & 15 & 18 & 3 & 0,035 \\
\hline 15 & 11 & 22 & 11 & 0,124 & 13 & 24 & 11 & 0,126 \\
\hline 16 & 8 & 24 & 16 & 0,174 & 15 & 17 & 2 & 0,024 \\
\hline 17 & 14 & 23 & 9 & 0.105 & 13 & 19 & 6 & 0,069 \\
\hline 18 & 13 & 17 & 4 & 0,046 & 14 & 19 & 5 & 0,058 \\
\hline 19 & 16 & 22 & 6 & 0,071 & 15 & 18 & 3 & 0,035 \\
\hline 20 & 18 & 23 & 5 & 0,061 & 12 & 18 & 6 & 0,068 \\
\hline$\sum$ & $\mathbf{2 6 1}$ & $\mathbf{4 3 6}$ & $\mathbf{1 7 5}$ & $\mathbf{2 , 0 0 3}$ & $\mathbf{2 9 7}$ & $\mathbf{3 9 8}$ & $\mathbf{9 9}$ & $\mathbf{1 , 1 5 5}$ \\
\hline Mean & $\mathbf{1 3 , 0 5}$ & $\mathbf{2 1 , 8}$ & $\mathbf{8 , 7 5}$ & $\mathbf{0 , 1 0 0}$ & $\mathbf{1 4 , 8 5}$ & $\mathbf{1 9 , 8}$ & $\mathbf{4 , 9 5}$ & $\mathbf{0 , 0 5 8}$ \\
\hline
\end{tabular}

Uji normalitas dimaksudkan untuk mengetahui apakah variabel dalam penelitian mempunyai sebaran distribusi normal atau tidak. Perhitungan uji normalitas ini menggunakan rumus Kolmogorov-Smirnov $Z$, dengan pengolahan menggunakan bantuan komputer program SPSS 16.

Tabel 2 Uji Normalitas Sebaran Data

\begin{tabular}{|c|c|c|c|c|c|c|}
\hline \multirow{2}{*}{ Kelas } & \multicolumn{3}{|c|}{ Kolmogorov-Smirnov } & \multicolumn{2}{|c|}{ Shapiro-Wilk } & \\
\hline & Statistic & Df & Sig. & Statistic & df & Sig. \\
\hline GSN Kelompok Eksperimen & .117 & 20 & .200 & .966 & 20 & .666 \\
\hline Kelompok Kontrol & .168 & 20 & .139 & .891 & 20 & .068 \\
\hline
\end{tabular}

Berdasarkan tabel 2, harga statistik Kolmogorov-Smirnov untuk kelas eksperimen $=0,117$ dengan signifikansi 0,666 (lebih besar dari 0,05) sehingga nilai statistik Kolmogorov Smirnov tidak signifikan. Ini berarti sebaran data untuk kelas eksperimen adalah normal. Demikian juga untuk kelas kontrol nilai statisk Kolmogorov Smirnov $=0,168$ dengan signifikansi 0,068 (lebih besar dari 0,05) sehingga nilai statistik Kolmogorov Smirnov tidak signifikan. Ini berarti sebaran data untuk kelas kontrol adalah normal.

Uji Homogenitas bertujuan untuk mengetahui data tersebut tergolong dalam homogen artinya data yang ada tidak terjadi ekstrim. 
Wiljiwianus Primus Wio Bei

Pengaruh Latihan Lari Zig-Zag, Lari Bolak-Balik, Push Up dengan Pola Circuit Training Terhadap Kesegaran Jasmani Siswa Ekstrakurikuler Sepak Bola SMAN I Soa Tahun Ajaran 2015/2016

Tabel 3 Uji Homogenitas Sebaran Data

\begin{tabular}{lllll}
\hline & $\begin{array}{l}\text { Levene } \\
\text { Statistic }\end{array}$ & df1 & df2 & Sig. \\
\hline GAIN Based on Mean & .616 & 1 & 38 & .437 \\
\cline { 2 - 6 } Based on Median & .741 & 1 & 38 & .395 \\
\hline $\begin{array}{l}\text { Based on Median and with } \\
\text { adjusted df }\end{array}$ & .741 & 1 & 37.656 & .395 \\
\hline Based on trimmed mean & .656 & 1 & 38 & .423 \\
\hline
\end{tabular}

Berdasarkan tabel 3 , nilai statistik hitung pada Based on Mean = 0.616 dengan signifikansi $=0.437$ (lebih besar $=0.05$ ) sehingga nilai statisik hitung tidak signifikan. Ini berarti varian kelas eksperimen dan kelas kontrol adalah homogen.

Data kelompok eksperimen dan kelompok kontrol digabungkan sehingga data tersebut dapat digunakan untuk menghitung uji hipotesis yang diambil dari data mean dan varians.

Tabel 4 Perhitungan Varians untuk menentukan Uji T.

\begin{tabular}{ccccc}
\hline & \multicolumn{3}{c}{ Kelas } & \multicolumn{2}{c}{ Kontrol } \\
\hline $\begin{array}{c}\text { No } \\
\text { Responden }\end{array}$ & GSn & GSn $^{2}$ & GSn & GSn $^{2}$ \\
\hline 1 & 0.071 & 0.005 & 0.035 & 0.001 \\
\hline 2 & 0.107 & 0.011 & 0.047 & 0.002 \\
\hline 3 & 0.146 & 0.021 & 0.024 & 0.001 \\
\hline 4 & 0.089 & 0.008 & 0.081 & 0.007 \\
\hline 5 & 0.111 & 0.012 & 0.036 & 0.001 \\
\hline 6 & 0.068 & 0.005 & 0.037 & 0.001 \\
\hline 7 & 0.128 & 0.016 & 0.116 & 0.014 \\
\hline 8 & 0.125 & 0.016 & 0.036 & 0.001 \\
\hline 9 & 0.094 & 0.009 & 0.081 & 0.007 \\
\hline 10 & 0.069 & 0.005 & 0.089 & 0.008 \\
\hline 11 & 0.080 & 0.006 & 0.049 & 0.002 \\
\hline 12 & 0.148 & 0.022 & 0.059 & 0.003 \\
\hline 13 & 0.081 & 0.007 & 0.049 & 0.002 \\
\hline 14 & 0.105 & 0.011 & 0.035 & 0.001 \\
\hline 15 & 0.124 & 0.015 & 0.126 & 0.016 \\
\hline 16 & 0.174 & 0.030 & 0.024 & 0.001 \\
\hline 17 & 0.105 & 0.011 & 0.069 & 0.005 \\
\hline 18 & 0.046 & 0.002 & 0.058 & 0.003 \\
\hline 19 & 0.071 & 0.005 & 0.035 & 0.001 \\
\hline 20 & 0.061 & 0.004 & 0.068 & 0.005 \\
\hline
\end{tabular}


Wiljiwianus Primus Wio Bei

Pengaruh Latihan Lari Zig-Zag, Lari Bolak-Balik, Push Up dengan Pola Circuit Training Terhadap

Kesegaran Jasmani Siswa Ekstrakurikuler Sepak Bola SMAN I Soa Tahun Ajaran 2015/2016

\begin{tabular}{|c|c|c|c|c|}
\hline$\Sigma$ & 2.003 & 0.222 & 1.155 & 0.083 \\
\hline Mean & 0.100 & 0.011 & 0.058 & 0.004 \\
\hline$S^{2}$ & 0.001 & & & \\
\hline
\end{tabular}

Diketahui

$\overline{X_{1}}$ kelompok eksperimen $=0,011$

$\overline{X_{2}}$ kelmpok control $=0,004$

$\mathrm{S}^{2}$ kelompok eksperimen $=0,001$

$\mathrm{S}^{2}$ kelompok eksperimen $=0,0009$ dengan menggunakan rumus $\mathrm{t}$

$t=\frac{\bar{X}_{1}-\bar{X}_{2}}{\sqrt{\frac{s_{1}^{2}}{n_{1}}+\frac{s_{2}^{2}}{n_{2}}}}$

Dari hasil analisis diperoleh nilai $\mathrm{t}=2,998$

Berdasarkan tabel 4 di atas selanjutnya dicari Nilai $t_{\text {hitung }}$ dengan rumus $u j i \mathrm{t}$ dan ditemukan nilai $t_{\text {hitung }}=2,998$ lebih besar dari nilai $t_{\text {tabel }}$ dengan $\mathrm{db}=38$, yaitu $=2,042$ pada taragf signifikansi $5 \%=(\alpha=0,05)$ yang berarti $(\mathrm{Ho})$ ditolak dan $(\mathrm{H} 1)$ diterima sehingga, terdapat perbedaan yang signifikan latihan lari zig-zag, lari bolak balik, dan push up antara kelas eksperimen dan kelas kontrol. Oleh karena rata-rata hitung kelas eksperimen $=0,1$ lebih besar rata-rata hitung kelas kontrol $=0,058$, maka latihan lari zig-zag, lari bolak balik, push-up dengan pola circuit training berpengaruh terhadap kesegaran jasmani pada siswa ekstrakurikuler sepak bola SMAN 1 Soa.

\section{Pembahasan}

Berdasarkan analisis data hasil penelitian diperoleh peningkatan yang signifikan terhadap kedua kelompok yang diteliti yakni kelompok kontrol dan eksperimen. Pemberian perlakuan selama 12 kali pertemuan dengan frekuensi 3 kali seminggu selama empat minggu memberikan pengaruh terhadap peningkatan kebugaran jasmani dari latihan lari zigzag, lari bolak-balik, dan push up terhadap siswa ektrakurikuler sepak bola SMAN 1 Soa.

Merujuk pada hasil analisis data penelitian ditemukan bahwa ada pengaruh latihan circuit training terhadap kebugaran jasmani siswa hal ini 
Wiljiwianus Primus Wio Bei

Pengaruh Latihan Lari Zig-Zag, Lari Bolak-Balik, Push Up dengan Pola Circuit Training Terhadap Kesegaran Jasmani Siswa Ekstrakurikuler Sepak Bola SMAN I Soa Tahun Ajaran 2015/2016

senada dengan Dwiyogo (2004:52) yang menyatakan bahwa circuit training merupakan suatu sistem latihan yang mampu menghasilkan perubahan-perubahan positif dalam motor performance juga memperbaiki secara serempak kesegaran jasmani secara keseluruhan dalam tubuh. Selanjutnya latihan Push up sebagai salah satu bentuk latihan kekuatan merupakan bagian dari unsur-unsur gerak yang mampu meningkatkan kesegaran jasmani. Push up adalah suatu jenis senam kekuatan yang berfungsi untuk menguatkan otot bisep maupun trisep. Posisi awal tidur tengkurap dengan tangan di sisi kanan kiri badan. Kemudian badan didorong ke atas dengan kekuatan tangan. Posisi kaki dan badan tetap lurus atau tegap. Setelah itu, badan diturunkan dengan tetap menjaga kondisi badan dan kaki tetap lurus. Badan turun tanpa menyentuh lantai atau tanah. Naik lagi dan dilakukan secara berulang. Selain itu Aktifitas gerakan lari bolak balik diprediksikan mampu meningkatkan kebugaran jasmani. Menurut Zivcic dkk. (2008) menyatakan bahwa salah satu latihan yang dapat meningkatkan kebugaran pada anak adalah shuttle run. Shuttle run adalah salah satu latihan kelincahan yang dilakukan dengan cara lari bolak-balik dari satu titik yang satu ke titik lainnya dengan jarak tertentu secara cepat. Pada saat melakukan shuttle run terjadi pergerakan persendian lengan dan terutama tungkai sehingga akan meningkatkan fleksibilitas. Kemudian, adanya kontraksi otot berulang akan menghasilkan kekuatan otot yang berguna untuk meningkatkan kecepatan gerak. Saat latihan berlangsung akan terjadi koordinasi fungsi otot yang berfungsi untuk meningkatkan ketepatan gerak dan memelihara keseimbangan. Fleksibilitas, kekuatan, kecepatan dan koordinasi adalah hal-hal yang diperlukan untuk meningkatkan kelincahan, sehingga jika semua komponen tersebut telah dilatih akan berpengaruh terhadap peningkatan kebugaran jasmani. Penelitian Nolvin (2013) menyebutkan ada peningkatan teknik zig-zag terhadap kebugaran jasmani. Pelatihan modifikasi zig zag run menerapkan gerakan-gerakan yang sangat kompleks yang hanya terfokus pada sistem kerja tungkai dimulai dari 
Wiljiwianus Primus Wio Bei

Pengaruh Latihan Lari Zig-Zag, Lari Bolak-Balik, Push Up dengan Pola Circuit Training Terhadap Kesegaran Jasmani Siswa Ekstrakurikuler Sepak Bola SMAN I Soa Tahun Ajaran 2015/2016

berlari, mengelilingi cone bahkan sampai melakukan gerakan berbelakbelok sehingga komponen biomotorik lainnya ikut terlatih.

\section{KESIMPULAN DAN SARAN}

\section{Kesimpulan}

Berdasarkan analisis dan pembahasan seperti yang telah diuraikan sebelumnya, maka penelitian ini dapat disimpulkan sebagai berikut:

1. Ada pengaruh latihan lari zig-zag dengan metode circuit training terhadap kesegaran jasmani siswa SMA 1 Soa.

2. Ada pengaruh latihan lari bolak-balik dengan pola circuit training terhadap kesegaran jasmani siswa ektrakurikuler sepak bola SMAN 1 Soa

3. Ada pengaruh latihan push up dengan pola circuit training terhadap kesegaran jasmani siswa ektrakurikuler sepak bola SMAN 1 Soa

\section{Saran}

Berdasarkan simpulan penelitian, disarankan beberapa hal yang berkaitandengan peningkatan kesegaran jasmani:

1. Untuk orang awam, pembina, pelatih dan guru olahraga serta atlet yang ingin memperbaiki dan meningkatkan kesegaran jasmani, harus mengetahui bahwa yang perlu ditingkatkan adalah kemampuan daya tahan sistem kardiovaskuler. Dengan sistem kardiovaskuler yang baik, maka segala aktifitas fisik juga lancar.

2. Untuk memperoleh kesegaran jasmani, lakukanlah latihan selama 6 minggu dengan frekuensi latihannya 3- 4 kali seminggu.

3. Bagi para peneliti diharapkan hasil penelitian ini dapat dijadikan pedoman atau acuan dalam melakukan penelitian selanjutnya dengan menambah waktu dan jarak dalam penelitian.

\section{DAFTAR PUSTAKA}

Batty. 2003. Latihan Sepak Bola: Metode Baru Serangan. Bandung: Pioner

Dwiyogo. 2004. Pengetahuan Kesegeran Jasmani.Malang: Media Pendidikan Olahraga Press. 
Wiljiwianus Primus Wio Bei

Pengaruh Latihan Lari Zig-Zag, Lari Bolak-Balik, Push Up dengan Pola Circuit Training Terhadap

Kesegaran Jasmani Siswa Ekstrakurikuler Sepak Bola SMAN I Soa Tahun Ajaran 2015/2016

Lutan, R. 2002. Pendidikan Kebugaran Jasmani Orientasi Pembinaan di Sepanjang Hayat. Yogyakarta: FIK UNY.

Luxbacher Joseph A. 2008. Sepak Bola. Jakarta: PT Rajagrafindo Persada.

Muhajir, 2007 Pendidikan Jasmani Olahraga dan Kesehatan. Yudistira : Jakarta.

Mahardika, M.I. Evaluasi Pengajaran, Surabaya: Unesa University Press.

Nolvin. 2013. Meningkatkan Kecepatan Lari Sprint Melalu Permainan Olahraga Tradisional Benteng Hadang Pada Siswa Kelas V Sd Inpres 2 Kamarora Kecamatan Nokilalaki Kabupaten Sigi . Jurnal Olah Raga.Pendidikan Jasmani, Kesehatan Dan Rekreasi FKIP Universitas Tadulako Kampus Bumu Tadulako Tondo Palu Sulawesi Tengah.

Sajoto, M. 1995. Peningkatan Pembinaan Kekuatan Kondisi Fisik Dalam Olahraga. Semarang: IKIP Semarang Press

Suharto. 2001. Pedoman dan Modul Peraturan Pelatih Fitness Center Tinggkat Dasa, Depdikbud dan Puskesjasrek.

Wayne. 2003. Building Strength Stamina. HumanKinetics.

Zivcic K., Bijana T., Manuela S. 2008. Changes In Some Of The Motor Abilities Of Preschool Children (Age Four). Physical Education and Sport. 6(1): 41-50. 